\title{
Usages of Salvia officinalis Boiled Water Extract for Pathogenic Escherichia coli Exclusion at Elevated Region
}

\author{
Sherifa Mostafa M. Sabra ${ }^{1 *}$ and Faten Abdulmouti Al-Salmi ${ }^{2}$ \\ ${ }^{1}$ Asst. Prof., Dr., Specialty Microbiology, Microbiology Br., Biology Dept., Science College, Taif University, KSA. \\ ${ }^{2}$ Asst. Lecturer, Specialty Microbiology, Microbiology Br., Biology Dept., Science College, Taif University, KSA. \\ Corresponding Author: Sherifa Mostafa M. Sabra. Asst. Prof., Dr., Microbiology, Technology and Science Deptartment Ranyah University \\ College, Taif University, KSA \\ Received date: January 12, 2021; Accepted date: January 16, 2021; Published date: February 18, 2021 \\ Citation: Sherifa M M. Sabra and Faten A. Al-Salmi (2021) Usages of Salvia officinalis Boiled Water Extract for Pathogenic Escherichia coli \\ Exclusion at Elevated Region J, Biotech. and Bioprocessing 2(3); DOI: 10.31579/2766-2314/026 \\ Copyright: (C) 2021, Sherifa Mostafa M. Sabra, This is an open access article distributed under the Creative Commons Attribution License, which \\ permits unrestricted use, distribution, and reproduction in any medium, provided the original work is properly cited.
}

\begin{abstract}
The aim was for tryout using daily regular Salvia officinalis boiled water extracts in "Arab and Saudi Society", especially at elevated region "Taif". That to prove its ability for pathogenic Escherichia coli exclusion and had antibiotic resistance. This could prove strength of chemical content and adherence of "Arab People" to use as regular and daily to stabilize body health and protect against pathogenic bacteria. Salvia officinalis was purchased from pharmacy at "Taif" and boiled water extract was made. Pathogenic Escherichia coli was obtained from a "Licensed Health Center"; culture was made and suspensions. Tryout by boiled water extract were added to bacterial suspension and then were kept in incubator. The samples were taken at hours $\left(1,3,5,7,9,11,13,15,17\right.$ and 19); were cultured and were kept for 48 hours at $37^{\circ} \mathrm{C}$. The exclusion percent's had determined, Escherichia coli exclusion mean percentages rose $5 \%$ at third hour and then increased $7 \%$ at fifth hour and at ninth hour was $8 \%$. Then it decreased at the eleventh hour and thirteenth hour $(2 \%$ and $3 \%$ ), then rose at the fifteenth hour $10 \%$. It decreased $5 \%$ at the seventeenth hour, and then returned and rose at the nineteenth hour $12 \%$. It was concluded Salvia officinalis boiled water extracts effects on pathogenic Escherichia coli exclusion was found during one growth bacteria cycle, indicated the characteristics of chemical contents and good daily habit. It was recommend continuing as "Arabian Habit" Salvia officinalis boiled water extracts for health and protection stability.
\end{abstract}

Keywords: salvia officinalis, boiled water extracts, arab and saudi society, elevated region, pathogenic, escherichia coli exclusion

\section{Introduction}

Salvia officinalis L. from family Lamiaceae is aromatic plant used in traditional medicine for treating mouth and throat inflammation [1]. It is cultivated in several countries mainly to obtain dried leaves to use raw material in medicine [2], it is one of the most popular traditional herbal medicines in Asian countries, [3]. It used in traditional medicine in Arabian country, which has essential oils rich in carvacrol [4]. The antibacterial properties related to their ability to give several secondary metabolites [5], they are effective against multidrug-resistant bacteria, as antibacterial activity [6]. An extract showed antibacterial, the effective compound and identified it as oleanolic acid, a triterpenoid, and they showed as antibacterial motion [7]. Extracts against Escherichia coli showed zone of inhibition as antibacterial action [8], it has the ability to stop growth of Escherichia coli [9]. Extracted the essential oils and used pathogenic bacteria resistant to many antibiotics as Escherichia coli ATCC 25922, that results indicated essential oils exhibit significant antibacterial activity, which are all very sensitive to raw and diluted essential oils. That can used to fight against infectious bacterial diseases [10]. The essential oil had a stronger antibacterial effect on Escherichia coli because of more strong antibacterial components (carvacrol and thymol) [11].

The aim was for tryout to use the daily regular Salvia officinalis boiled water extracts in the "Arab and Saudi Society", especially at elevated region "Taif". That to prove its ability for Escherichia coli exclusion as pathogenic bacteria and have antibiotic resistance characteristics. This could prove the strength of the chemical content and adherence of "Arab People" to use as regular and daily Salvia officinalis boiled water extracts to stabilize the state of body health and protect body against pathogenic bacteria that caused diseases.

\section{Materials and methods}

- Salvia officinalis: It was purchased from "Licensed Places" as the pharmacy in the elevated region "Taif", it was licensed as it was pure medicinal and free of any additives. The boiled water extract was made by placing (five grams $+200 \mathrm{ml}$ boiled sterile water) [12]

- Escherichia coli: It was obtained from a "Licensed Health Center"; it was isolated from a patient and identified as pathogenic Escherichia coli. A culture was made on "MacConkey Agar Plate", 
and then wad made suspensions in "Peptone Water" in a degree of "0.5, McFarland's Guide" [13].

- Tryout: Five $\mathrm{ml}$ of the boiled water extract were added to $0.2 \mathrm{ml}$ of bacterial suspension in three separate tubes, and then were kept in incubator. The samples were taken from each tubes at hours $(1,3,5$, 7, 9, 11, 13, 15, 17 and 19); which accompanied with bacterial life cycle. Every hours mentioned inoculums from each tubes were taken then were cultured on a separate "MacConkey Agar Plate" and were
- $\quad$ kept for 48 hours at $37{ }^{\circ} \mathrm{C}$. Growth colonies were recorded, the exclusion percent's had determined from Equation (100 - Growth colonies percent $=$ Exclusion colonies percent $)$. The mean percent's of the three dishes were calculated [14].

- Information enquiry: The results were evaluated by "Excel Online" [15].

\section{Results and discussion}

\begin{tabular}{|l|c|c|c|c|c|c|c|c|c|c|}
\hline Items & \multicolumn{9}{|c|}{ Escherchia coli exclusion percent } \\
\hline Hour & $\mathbf{1}$ & $\mathbf{3}$ & $\mathbf{5}$ & $\mathbf{7}$ & $\mathbf{9}$ & $\mathbf{1 1}$ & $\mathbf{1 3}$ & $\mathbf{1 5}$ & $\mathbf{1 7}$ & $\mathbf{1 9}$ \\
\hline Plate 1 & $10 \%$ & $15 \%$ & $25 \%$ & $30 \%$ & $35 \%$ & $40 \%$ & $40 \%$ & $50 \%$ & $60 \%$ & $70 \%$ \\
\hline Plate 2 & $15 \%$ & $20 \%$ & $25 \%$ & $30 \%$ & $40 \%$ & $40 \%$ & $45 \%$ & $55 \%$ & $55 \%$ & $70 \%$ \\
\hline Mean & $\mathbf{1 3 \%}$ & $\mathbf{1 8 \%}$ & $\mathbf{2 5 \%}$ & $\mathbf{3 0 \%}$ & $\mathbf{3 8 \%}$ & $\mathbf{4 0 \%}$ & $\mathbf{4 3 \%}$ & $\mathbf{5 3 \%}$ & $\mathbf{5 8 \%}$ & $\mathbf{7 0 \%}$ \\
\hline
\end{tabular}

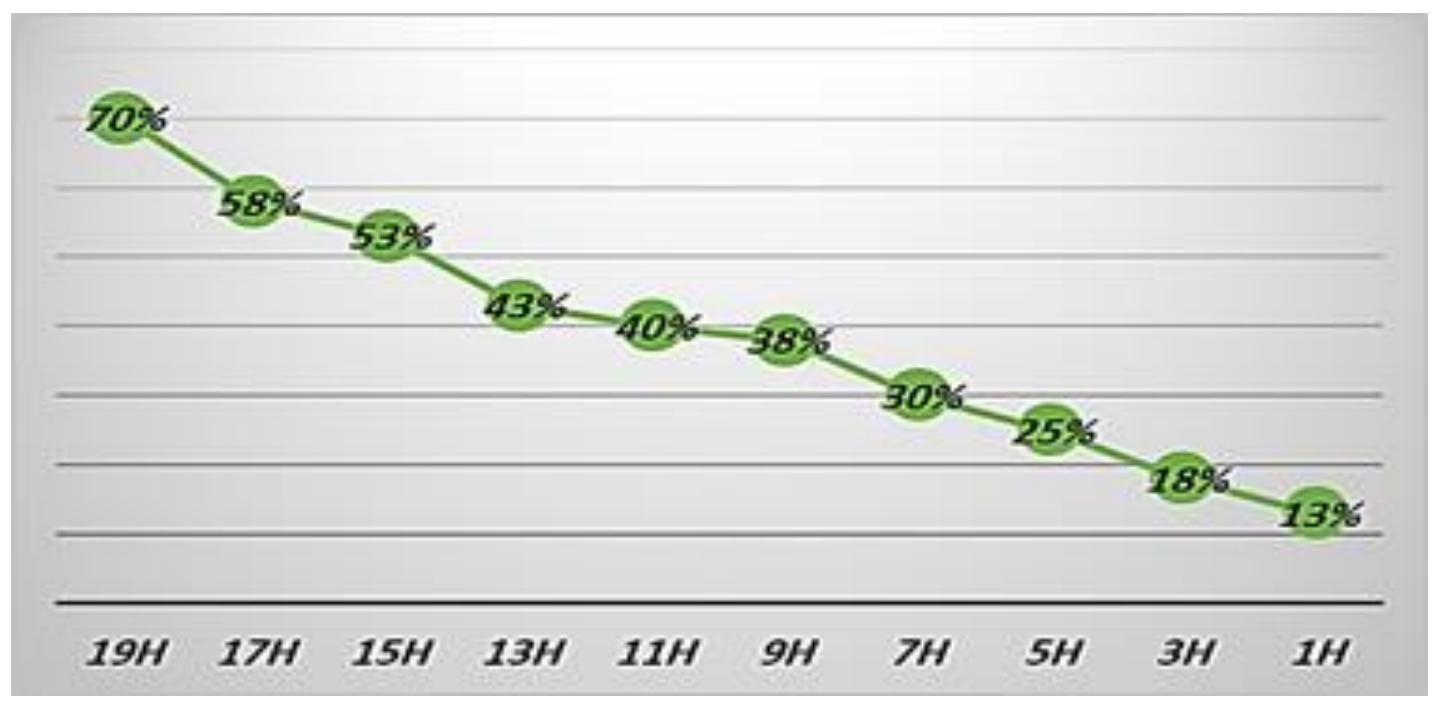

Table 1 and graph 1. Mean percentages of Escherichia coli exclusion

Table 1 and graph 1 displayed mean percentages of Escherichia coli exclusion, the average rose by $5 \%$ at third hour and in the early stages, then it began to increase to $7 \%$ at fifth hour and at ninth hour was $8 \%$. Then it decreased at the eleventh hour and thirteenth hour to (2\% and $3 \%)$, but it rose again at the fifteenth hour to $10 \%$. It decreased again to $5 \%$ at the seventeenth hour, and then returned and rose very significantly at the nineteenth hour to $12 \%$. The effect on the degrees and percentages of Escherichia coli exclusion may depend on the growth stages. As for increasing the rate of Escherichia coli exclusion, taking an acceptable ascending path, since the bacteria are pathogenic and resistant to some antibiotics. The Salvia officinalis boiled water extracts used because it is using in the Arab community in the same daily way. Therefore, we did not change the method of use to obtain the usual daily results for the ticks that using the Salvia officinalis boiled water extracts. It considered one of the basic old regular drinks in Saudi society, especially in elevated region such as "Taif" [1-11]. The results were useful for the experiment as it is using in the same daily usual way for the Arab community, especially the Saudi society, due to the importance of the simple Salvia officinalis boiled water extracts. It is useful for the Salvia officinalis as anti-bacterial and fatal properties, that is, it has the ability to Escherichia coli exclusion most caused of diseases to individuals because of the chemical content. It found, from the Salvia officinalis boiled water extracts were useful for protecting against the occurrence of Escherichia coli infections and the stability of individual health occurs continuously [1-11]. Regular daily use has imitated by grandparents and benefits knowledge of the Salvia officinalis boiled water extracts from the ancestors and from the history of use, although there was not any information on its chemical contents and formulations during the time of the ancestors [1-11].

\section{Conclusion}

It was concluded that the effect of Salvia officinalis boiled water extracts on pathogenic Escherichia coli exclusion was found during one growth cycle of the bacteria, which indicated the characteristics of the chemical contents and as a good daily habit.

\section{Recommendation}

It was recommend that the continuing to use Salvia officinalis boiled water extracts for the stability of health and protection as "Arabian Habit".

\section{References}

1. Baricevic, D., Sasa, S., Della Loggia, R., Tubaro, A., Simonovska, B., et al (2001) Topical anti-inflammatory activity of salvia officinalis L. leaves: the relevance of urosolic acid. $J$. Ethnopharmacol., 75: 125-132.

2. Lasseigne T., Stuart, W., Frank B. \& Thomas, R., (2007) Day/Night temperature affects growth and photosynthesis of Cultivated salvia Taxa. J. Amer. Soc. Hort. Sci., 132 (4): 492-500.

3. Jiang, W., Lau, M., Hon, M., Thomas, M., Woo S., \& Fung, P., (2005) Chemistry and biological activities of caffeic Acid derivatives from Salvia Miltiorrhiza. Crr. Med. Chem., 12: 237246. 
4. Bruneton, J., (1993) Pharmacognosie, phytochimie, plantes médicinales, quatrième édition. Lavoisier, 580.

5. Matasyoh, J., Maiyo, Z., Ngure, R. \& Chepkorir, R., (2009) Chemical composition and antimicrobial activity of the essential oil of Coriandrumsativum. Food Chem., 113 (2): 526-529.

6. Eidi, A. \& Baharc, M., (2006) Effects of Salvia officinalis L. (sage) leaves on memory retention and its interaction with the cholinergic sy stem in rats. Applied and Basic Nutritional Sci., 22 (3): 321-326.

7. Kumiko, H., Sumiko, H., Tsutomu, H., Takashi, Y., Teruo, K. \& Tomofusa, A., (2005) Antimicrobial activity of oleanolic acid from Salvia officinalis and related compounds on vancomycin resistance enterocoocci (VRE). Bio. and pharma. Ball. 30 (6): 1147-1149.

8. Ali, M. \& Aboud, A., (2010) Antimicrobial activities of aqueous and methanolic extracts from Salvia officinalis and Salix acmophylla used in the treatment of wound infection isolates. Ibn Al-Hatham J. for Pure \& Appl. Sci, 23 (3): 2010.

9. Hassan, A., Hemeg, A., Ihab, M., Moussa, B., Sherin, D., et al. (2020) Antimicrobial effect of different herbal plant extracts against different microbial population. Saudi J. Bio. Sci., In Press.
10. Derradji, L., Saidi, O. \& Hadef, Y., (2020) Evaluation of the antibacterial activity of three essential oils extracted from plants used in traditional medicine in Algeria (Salvia officinalis L, Melissa officinalis L and Origanum vulgare L). GSC Biological and Pharmaceutical Sci., 12 (01): 181-188.

11. Rahchamani, R., Zarooni, S. \& Ghanbari, F., (2020) Effect of essential oils of Salvia officinalis and Satureja hortensis on Staphylococcus aureus, Streptococcus agalactiae and Escherichia coli. DOI:10.22092/vj.2020.341736.1687.

12. Nefeli, S., Sotiropoulou, S., Stiliani, F., \& Petros, T., (2020) Evaluation of antioxidant activity, toxicity, and phenolic profile of aqueous extracts of chamomile (Matricaria chamomilla L.) and Sage (Salvia officinalis L.) prepared at different temperatures. Appl. Sci., 10 (7): 2270.

13. Dlusskaya, E., McMullen, L. \& Gänzle, M., (2011) Characterization of an extremely heat-resistant Escherichia coli obtained from a beef processing facility. J. Appl. Micro., 110 (3): 840-9.

14. Aseptic Laboratory Techniques: Plating Methods DOI: $10.3791 / 3064$

15. Excel on line, https://chrome.google.com/webstore/detail/excelonline/iljnkagajgfdmfnnidjijobijlfjfgnb. 2020 Commons Attribution 4.0 License

\section{To Submit Your Article Click Here: Submit Manuscript}

DOI: $10.31579 / 2766-2314 / 026$
Ready to submit your research? Choose Auctores and benefit from:

* fast, convenient online submission

* rigorous peer review by experienced research in your field

* rapid publication on acceptance

* authors retain copyrights

* unique DOI for all articles

* immediate, unrestricted online access

At Auctores, research is always in progress.

Learn more www.auctoresonline.org/journals/biotechnology-andbioprocessing 